\title{
Yield and Disease Responses of Improved Groundnut Genotypes Under Natural Disease Infection in Northern Uganda: Implication for Groundnut Disease Management
}

\author{
Alfred Kumakech ${ }^{1}$, Godfrey A. Otim ${ }^{1}$, Tonny Opio ${ }^{1}$, Alfred Komakech ${ }^{2} \&$ Laban F. Turyagyenda $^{1}$ \\ 1 Ngetta Zonal Agricultural Research and Development Institute, National Agricultural Research \\ Organization, Entebbe, Uganda \\ ${ }^{2}$ Project for the Restoration of Livelihood in Northern Region, Kampala, Uganda \\ Correspondence: Alfred Kumakech, Ngetta Zonal Agricultural Research and Development Institute, National \\ Agricultural Research Organization, P.O. Box 295, Entebbe, Uganda. E-mail: kumalfred@gmail.com
}

\author{
Received: June 7, $2021 \quad$ Accepted: July 12, $2021 \quad$ Online Published: December 15, 2021 \\ doi:10.5539/jas.v14n1p70 URL: https://doi.org/10.5539/jas.v14n1p70
}

\begin{abstract}
Groundnut production in Uganda is constrained by groundnut rosette disease (GRD), the main cause of yield loss experienced by farmers. We conducted the current study to assess the responses of improved groundnuts to diseases (rosette and late leaf spot) and yield under local conditions. Four released groundnut genotypes (Serenut 5R, Serenut 8R, Serenut 9T and Serenut 14R) were evaluated in four locations in northern Uganda for two seasons in 2019. We established the experiment following randomised complete block design with three replications. GRD severity (harvest) and late leaf spot (LLS) severity (harvest) on the four genotypes were not significantly $(\mathrm{P}>0.05)$ different but positively correlated with the Area Under Disease Progress Curve (AUDPC). Genotype-by-location interaction for LLS AUDPC, GRD AUDPC and dry pod yield were significant $(\mathrm{P}<.001)$. Season-by-genotype interaction was not significant $(\mathrm{P}=0.367)$. Days to $50 \%$ flowering were also not significant $(\mathrm{P}>0.05)$. Highest and lowest yields were recorded for Serenut 9T in the Omoro district (1,291 kg/acre) and the Amuru district (609 kg/acre), respectively. Dry pod yield was significantly $(\mathrm{P}<0.001)$ negatively correlated with GRD severity and GRD AUDPC. Yield performance of the four genotypes was not significantly $(\mathrm{P}<0.05)$ different in the districts, except for Kitgum, where yields of Serenut 9T and Serenut $8 \mathrm{R}$ were significantly $(\mathrm{P}<0.05)$ higher. These genotypes could be used to manage GRD by smallholder farmers in Northern Uganda. Special consideration should therefore be given to these four groundnut genotypes for GRD management in the Acholi sub-region.
\end{abstract}

Keywords: Arachis hypogaea, Area Under Disease Progress Curve, severity, resistance

\section{Introduction}

Groundnut (Arachis hypogaea L.) is an important oil seed crop in arid and semi-arid regions of the world (Thakur et al., 2013). Uganda is one of the major producers of groundnuts in Africa (Shiferaw et al., 2010). In Uganda, the groundnut is the second most important food legume after beans (Okello et al., 2014b). The crop provides multiple benefits to smallholder farmers in rural areas. It is a cheap source of protein to households with limited access to expensive animal diets (Rachier, 2005). The crop is also a source of household income. Collectively, this makes groundnut an important food security crop in both rural and urban areas of Uganda (Obuo et al., 2004). While groundnut is hugely important as highlighted above, its productivity in Uganda is still very low, estimated at less than $800 \mathrm{~kg} / \mathrm{ha}$ yet yields as high as $2500 \mathrm{~kg}$ to $3000 \mathrm{~kg} / \mathrm{ha}$ can be achieved (Okello et al., 2017; Okello et al., 2014a). A combination of biotic (pests and diseases), abiotic (drought at critical stages) and socio-economic factors are key limitations to the productivity of groundnut.

Pests and diseases are among the major production constraints of groundnuts in Uganda. Major diseases include late leaf spots (LLS) caused by the fungus Phaeoisariopsis personatum (Okello et al., 2013) and groundnut rosette disease (GRD) caused by a virus complex of two viruses (groundnut rosette virus and groundnut rosette assistor virus) and a nucleic acid molecule known as satellite RNA (Okello et al., 2014a). Late leaf spot infection occurs 55-57 days after sowing. The spots are usually circular on lower surface, in concentric rings. Spot on upper leaf surface are brown to black, tending towards black, while on the lower leaf surface the spots 
are black (Okello et al., 2013). Among diseases, Groundnut rosette disease (GRD) is the most important (Mugisa et al., 2016; Okello et al., 2010). According to Mugisa et al. (2016) groundnut rosette disease can cause total crop failure when susceptible genotypes are grown. The disease occurs in all groundnuts growing regions of Uganda and it is characterized by unpredictable epidemics (Okello et al., 2010). Improving cropping practices and breeding for host-plant resistance have been the focus of GRD control in Uganda (Okello et al., 2014a). Collaboration between the National Agricultural Research Organisation (NARO) of Uganda and International Crops Research Institute for the Semi-Arid Tropics (ICRISAT) resulted in release of groundnut rosette resistant varieties such as Serenut 5R, 6T, 7T, 8R, 9T, 10R, 11T, 12R, 13T, and 14R (Okello et al., 2013, 2015). The resistant varieties have important traits including high yield potential, drought tolerance, and seed characteristics that are critical for meeting consumer demand (Busolo-Bulafu, 2004). Although groundnut resistant varieties are available and could be used in subsistence agriculture, performance of the resistant varieties under different agro-ecological conditions in northern Uganda is not fully known.

Research on cropping practices has led to the development of control options for GRD. Such practices are either capital or knowledge-intensive, thus limiting their adoption. According to Mugisa et al. (2016), management practices such as intercropping, planting at close spacing, petsicide application and rogueing does not significantly reduce GRD incidence and severity of in farmers' fields. Use of improved varieties and early sowing are however, effective in controlling GRVD in farmers' fields (Mugisa et al., 2016). The most reliable and easy to adopt control method of GRD is therefore, the cultivation of resistant genotypes (Shiferaw et al., 2010; Busolo-Bulafu, 2004). Thus, the availability of high yielding and disease resistant varieties adapted to conditions offers the most cost effective long-term control measure for sustainable production of groundnuts (Kueneman, 2002). Such varieties however, must show high performance for important agronomic traits and their dominance should be consistent over a wide range of production environments (Kaketo et al., 2018). Identification and promotion of improved varieties with farmer-preferred traits in northern Uganda is important. According to Minde et al. (2017), stable genotypes adjust their phenotypic responses to provide some measure of uniformity in spite of environmental fluctuations.

Multi-environment adaptive trials are conducted to ensure that selections made have a reliable and a predictable performance in farmers' fields (Sahoo et al., 2017; Fliert, et al., 2010). The goal is usually to identify superior cultivars for a target location (Trouchea et al., 2010). Good adaptive capacity means superior productivity of a genotype (Adee et al., 2016; Alvaro et al., 2008). The actual yield and consistency of yield of an improved variety is an index of adaptation, although yield is an outcome of several processes at all stages in the growth and development of the crop (Maiti et al., 2014; Powell et al., 2012). Therefore, assessment of adaptation should include evaluation of responses to abiotic stresses, phonological and genetic performance. Development of new varieties requires full participation of stakeholders (Scoones et al., 2009). On-farm trials provide vital tools for enhancing cultivar adoption rates in farming communities (Kakeeto et al., 2018; Joshi et al., 2007; Assefa et al., 2005). According to Kaizzi et al., 2006, on-farm trials enable the incorporation of farmers' opinions and ensure testing of technologies under farmers' management conditions. Sibiya et al. (2013) reported increased rates of adoption and reduced variety abandonment where farmers' knowledge and experiences are acknowledged.

In this paper, the responses of 4 improved groundnut genotypes to natural late leaf spot and groundnut rosette disease pressures, their growth and yield performances under local conditions in northern Uganda were evaluated for two cropping seasons in 2019 with a view to identifying most adapted genotypes.

\section{Materials and Methods}

\subsection{Planting Materials}

The planting materials used in this study consisted of four released groundnut varieties (Table 1), developed for high yield and resistance to foliar diseases. 
Table 1. Key attributes of commercial groundnut varieties included in the study

\begin{tabular}{|c|c|c|c|c|}
\hline \multirow{2}{*}{ Variety name } & \multirow{2}{*}{ Year of release } & \multicolumn{3}{|c|}{ Key attributes } \\
\hline & & Maturity period (days) & Grain yield (tons/ha) & Special attributes \\
\hline Serenut 5R & 2010 & $100-110$ & 2.5 & $\begin{array}{ll}\text { - } & \text { Tolerant to drought } \\
\text { - } & \text { Rosette \& leaf spot resistant }\end{array}$ \\
\hline Serenut 8R & 2011 & $100-110$ & 2.5 & $\begin{array}{ll}\text { - } & \text { Tolerant to drought } \\
\text { - } & \text { Rosette \& leaf spot resistant } \\
\end{array}$ \\
\hline Serenut 9T & 2011 & $100-110$ & 2.5 & $\begin{array}{ll}\text { - } & \text { Tolerant to drought } \\
\text { - } & \text { Easy to shell } \\
\text { - } & \text { Stay green }\end{array}$ \\
\hline Serenut 14R & 2011 & $100-110$ & 2.5 & $\begin{array}{l}\text { - Tolerant to drought } \\
\text { - } \quad \text { Rosette \& leaf spot resistant } \\
\text { - Stay green }\end{array}$ \\
\hline
\end{tabular}

\subsection{Experimental Sites}

The experiment was conducted at Ngetta Zonal Agricultural Research and Development Institute (Ngetta ZARDI) satellite station in Kitgum $\left(02^{\circ} .13697^{\prime} \mathrm{N}\right.$; $\left.032^{\circ} .51702^{\prime} \mathrm{E}\right)$, Omoro $\left(02^{\circ} .42432^{\prime} \mathrm{N}\right.$; $\left.032^{\circ} .32037^{\prime} \mathrm{E}\right)$, Amuru $\left(02^{\circ} .49045^{\prime} \mathrm{N} ; 031^{\circ} .52229^{\prime} \mathrm{E}\right)$ and Nwoya $\left.02^{\circ} .45632^{\prime} \mathrm{N} ; 031^{\circ} .54264^{\prime} \mathrm{E}\right)$ districts in 2019 during the first and second rainy seasons, March to June and August to December respectively.

\subsection{Experimental Design}

All the experiments were established following a randomized complete block design (RCBD) with three replications. The size of the experimental plot was $5 \times 5 \mathrm{~m}$ with spacing of $45 \mathrm{~cm}$ between rows and $15 \mathrm{~cm}$ between plants in the rows. Each plot contained 370 plants. Local groundnut (Alur) which is highly susceptible to LLS and GRD was included to maximize late leaf spot (LLS) and groundnut rosette diseases (GRD) inoculum pressure under natural conditions. Local groundnut was planted the same time with experimental materials. All recommended agronomic practices including timely weeding were followed.

\subsection{Data Collection}

Late leaf spot disease severity scoring was done at $4,8,12$ weeks after planting and at harvesting using a scale of $1-9$, where $1=0 \%$ foliar infection; $2=1-5 \% ; 3=6-10 \% ; 4=11-20 \% ; 5=21-30 \% ; 6=$ $31-40 \% ; 7=41-60 \% ; 8=61-80 \%$ and $9=81-100 \%$ of foliar area infection with plants having almost all leaves defoliated leaving bare stems (Khalid et al., 2018). Genotypes with a disease score 1-3 = resistant, 4-5 = moderate resistance, 6-7 = susceptible and 8-9 = highly susceptible.

Groundnut rosette disease incidence was assessed at 4, 8, and 12 weeks after planting and expressed as the percentage of plants infected with GRD over the total number of plants in the plot. Disease severity was scored at 12 weeks after planting using a scale of 1-9 based on the intensity of disease attack (Khalid et al., 2018; Okello et al., 2014), where 1-3 = resistant with no or negligible leaf symptoms [where $1=$ resistant with no symptom, 2 = very slight leaf symptoms and 3 = slight leaf symptoms but still negligible]; 4-6 = moderately resistant with leaf symptoms and no stunting [where $4=$ showed $50 \%$ symptoms on leaves, $5=$ all leaves showed symptom of chlorosis and 6 is $25 \%$ stunted]; $7-9=$ susceptible [where all leaves showed symptom of chlorosis, 7 showed $50 \%$ stunted, 8 and 9 severe leaf symptoms with $>50 \%$ stunt where $8=$ had few pods while $9=$ no pod at all).

\subsubsection{Dry Pod Yield}

Pods were collected from each plot at harvest, dried and were weighed in kilograms $(\mathrm{kg})$. Plot yield were converted to kilogram per acre ( $\mathrm{kg} / \mathrm{acre})$.

\subsection{Data Analysis}

Data were normalized, following tests for normality. Late leaf spot severity data and GRD incidence data were used to calculate the Area Under Disease Progress Curve (AUDPC) (Madden et al., 2007) prior to statistical analysis. Analysis of variance (ANOVA) were performed in GENSTAT statistical package $16^{\text {th }}$ edition (Payne et al., 2011). The means were separated using least significant difference (LSD). 


\section{Results}

\subsection{Late Leaf Spot Disease and Groundnut Rosette Disease Severity}

The results of the response of the 4 improved varieties to LLS and GRD infection under natural infections in the field is presented in Table 2 . A highly significant difference $(P<.001)$ in LLS severity at harvest, LLS AUDPC and GRD AUDPC was recorded for genotype by location interaction. Highest and lowest LLS severity was recorded on Serenut 14R in Amuru District and Serenut 8R in Omoro District, respectively. Overall, LLS severity on the 4 improved groundnut varieties was significantly $(\mathrm{P} \leq 0.05)$ lower than LLS severity on local checks in the 4 locations. Average disease score for all the genotypes across locations was in the rage of 4-5. GRD severity among the 4 varieties tested was not significant at $\mathrm{P} \leq$ 0.05. GRD severity ranged from 1.5 to 3.5 . The highest and lowest GRD severity was recorded on Serenut 8R in Amuru District and Serenut 9T in Omoro District, respectively. GRD severity on the tested varieties was however, significantly $(\mathrm{P}<.001)$ lower than GRD severity on the local check in the 4 locations. Significant difference $(\mathrm{P} \leq 0.031)$ of genotype-by-season interactions for LLS AUDPC was recorded. GRD AUDPC was not significant $(\mathrm{P}=0.951)$ for genotype-by-season interactions.

Table 2. Means and LSD of LLS severity, GRD severity, LLS AUDPC and GRD AUDPC parameters of 4 groundnut genotypes evaluated in northern Uganda in seasons A and B, 2019

\begin{tabular}{|c|c|c|c|c|c|c|c|c|c|c|c|c|c|c|c|c|c|c|c|c|}
\hline \multirow{2}{*}{ Variety } & \multicolumn{5}{|c|}{ LLS severity 12 weeks } & \multicolumn{5}{|c|}{ GRD severity harvest } & \multicolumn{5}{|c|}{ LLS AUDPC } & \multicolumn{5}{|c|}{ GRD AUDPC } \\
\hline & A & $\mathrm{N}$ & $\mathrm{O}$ & $\mathrm{K}$ & LSD & A & $\mathrm{N}$ & $\mathrm{O}$ & $\mathrm{K}$ & LSD & A & $\mathrm{N}$ & $\mathrm{O}$ & $\mathrm{K}$ & LSD & A & $\mathrm{N}$ & $\mathrm{O}$ & $\mathrm{K}$ & LSD \\
\hline S.5R & 4.7 & 4.5 & 4.2 & 4.3 & 0.9 & 3.2 & 2.0 & 1.3 & 2.7 & 2.4 & 17.0 & 16.3 & 13.3 & 20.3 & 4.2 & 52.0 & 13.5 & 7.8 & 54 & 46.7 \\
\hline S. $8 \mathrm{R}$ & 4.8 & 4.3 & 3.3 & 4.0 & 0.8 & 3.5 & 1.7 & 1.3 & 2.2 & 2.2 & 14.7 & 13.7 & 12.7 & 17.3 & 2.8 & 64.0 & 14.0 & 6.0 & 24.8 & 40.2 \\
\hline S.9T & 4.8 & 4.2 & 3.7 & 3.8 & 0.8 & 2.3 & 1.5 & 1.3 & 2.0 & 1.9 & 13.0 & 13.0 & 13.0 & 17.3 & 4.3 & 30.0 & 7.8 & 5.3 & 19.7 & 20.9 \\
\hline S.14R & 5.0 & 3.8 & 4.0 & 3.8 & 0.6 & 3.2 & 1.8 & 1.3 & 3.0 & 1.8 & 13.7 & 14.3 & 12.7 & 15.7 & 2.9 & 52.0 & 9.0 & 10.2 & 31.3 & 26.3 \\
\hline Local check & 6.8 & 7.5 & 6.3 & 8.2 & 0.8 & 7.7 & 5.8 & 4.8 & 5.0 & 2.2 & 20.0 & 19.7 & 19.3 & 29.7 & 4.7 & 277.7 & 79.7 & 93.5 & 52.0 & 121.8 \\
\hline LSD & 0.8 & 0.8 & 0.7 & 0.8 & & 2.5 & 1.7 & 1.6 & 2.3 & & 3.6 & 4.0 & 3.1 & 3.9 & & 109.3 & 23.0 & 29.6 & 51.0 & \\
\hline
\end{tabular}

Note. S.5R: Serenut 5R; S.8R: Serenut 8R; S.9T: Serenut 9T, S.14R: Serenut 14R; A: Amuru district; N: Nwoya district; O: Omoro district; K: Kitgum district; LLS severity 12 weeks: Late leaf spot score at 12 weeks after planting; LLS AUDPC: Late leaf spot-Area Under Disease Progress Curve; GRD severity harvest: Groundnut rosette disease score at harvest; GRD AUDPC: Groundnut rosette disease-Area Under Disease Progress Curve.

\subsection{Yield Potential}

Results of days to $50 \%$ flowering and yields of the 4 genotypes tested are presented in Table 3. Days to $50 \%$ flowering was not significant $(\mathrm{P} \leq 0.05)$ in all the 4 locations. Local check however, exhibited a significantly $(\mathrm{P}<.001)$ lower days to $50 \%$ flowering. Highly significant difference $(\mathrm{P}<.001)$ in yields of the 4 varieties was recorded. Genotype by location interaction was also significant $(\mathrm{P}=0.044)$. The highest and lowest yield was recorded for Serenut 9T (1291 kg/acre) in Omoro District and Serenut 9T (609 kg/acre) in Amuru district, respectively. Genotype by sesason interaction was not significant $(\mathrm{P}=0.230)$ for yield.

Table 3. Means and LSD of days to $50 \%$ flowering and yield of 4 groundnut genotypes grown in northern Uganda in 2019A and 2019B seasons

\begin{tabular}{|c|c|c|c|c|c|c|c|c|c|c|}
\hline \multirow{2}{*}{ Variety } & \multicolumn{5}{|c|}{ Days to $50 \%$ flowering } & \multicolumn{5}{|c|}{ Dry pod yield (kg/acre) } \\
\hline & A & $\mathrm{N}$ & $\mathrm{O}$ & $\mathrm{K}$ & LSD & A & $\mathrm{N}$ & $\mathrm{O}$ & $\mathrm{K}$ & LSD \\
\hline Serenut 5R & 31.2 & 29.0 & 28.7 & 27.0 & 2.3 & 876 & 844 & 1076 & 852 & 201 \\
\hline Serenut 8R & 31.7 & 29.3 & 28.0 & 27.3 & 2.3 & 767 & 874 & 1142 & 859 & 253 \\
\hline Serenut 9T & 31.8 & 29.2 & 27.7 & 27.2 & 2.4 & 609 & 914 & 1291 & 1122 & 394 \\
\hline Serenut 14R & 31.7 & 28.3 & 28.3 & 26.2 & 2.4 & 815 & 956 & 1154 & 930 & 289 \\
\hline Local check & 25.7 & 24.7 & 23.7 & 24.3 & 1.3 & 483 & 205 & 614 & 407 & 214 \\
\hline LSD & 2.7 & 2.2 & 2.1 & 1.9 & & 290 & 206 & 330 & 240 & \\
\hline
\end{tabular}


Overall performance of the tested genotypes was better in 2019B season in Omoro, Nwoya and Amuru, while season 2019A performance was better than 2019B season in Kitgum District for all the tested genotypes (Figure 1).

\subsection{Relationship between Disease (LLS and GRD) Severity and Yield}

The result of correlation analysis is presented in Table 4. Late leaf spot disease AUDPC and GRD AUDPC showed highly significant $(\mathrm{P}<0.01)$ positive correlation with LLS severity at 12 weeks and GRD severity at harvest, respectively. Dry pod yield $(\mathrm{kg} / \mathrm{acre})$ showed highly significant $(\mathrm{P}<0.001)$ negative correlation with GRD severity at harvest $(r=-0.437)$ and GRD AUDPC $(r=-0.562)$.

Table 4. Correlation of disease severity, AUDPC and dry pod yield

\begin{tabular}{lllllll}
\hline Traits & DT50\% F & LLS At 12w & LLS AUDPC & GRD AUDPC & GRD severity & Dry pod yield kg/acre \\
\hline DT50\%F & - & & & & & \\
LLS at12weeks & $0.147^{*}$ & - & & & & \\
LLS AUDPC & $0.109^{*}$ & $0.810^{* *}$ & - & & \\
GRD AUDPC & $-0.144^{* *}$ & -0.005 & 0.001 & - & & \\
GRD severity & $-0.131^{*}$ & -0.064 & -0.064 & $0.585^{* *}$ & - & - \\
Dry pod yield kg/acre & $-0.170 * *$ & -0.083 & -0.008 & $-0.562^{* *}$ & $-0.437^{* *}$ & - \\
\hline
\end{tabular}

Note. ${ }^{*}=$ significant; $* *=$ highly significant.
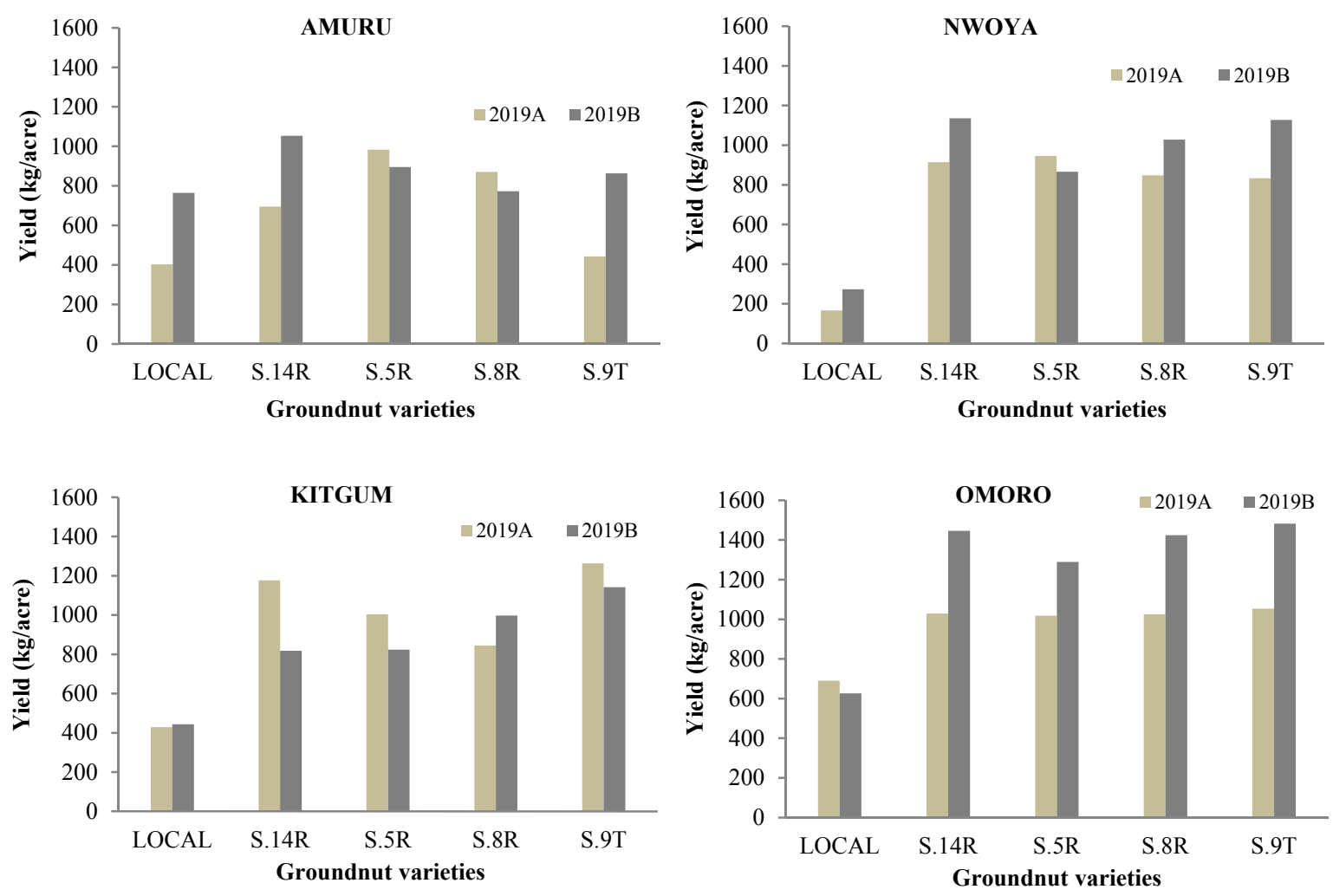

Figure 1. Comparing 2019A and 2019B season yield of Serenut 5R, Serenut 8R, Serenut 9T and Serenut 14R in four districts in Acholi

\section{Discussion}

The purpose of this study was to establish the effect of groundnut genotypes with proven resistance against rosette virus on yield under different disease pressure in Northern Uganda. All four tested genotypes showed high levels of partial resistance as demonstrated by low AUDPC values during GRD epidemics. Late leaf spot and GRD severity within the districts were not significant for the genotypes indicating limited genetic 
variability in the genotypes for LLS and GRD severity. Late leaf spot severity score ranged between 4 and 5 , GRD severity ranged from 1.5 to 3.5 , indicating that these genotypes were moderately resistant under local conditions in Northern Uganda.

Significant difference of genotype-by-location interactions for LLS AUDPC, GRD AUDPC and yield was observed. This difference could be due variation in disease pressure, resulting in exposure of the genotypes to different levels of inoculum. The reduced yields of some genotypes in GRD high pressure district of Amuru and Kitgum districts could be attributed to yield penalty associated with resistance to GRD due to the plants spending energy to express the genes of resistance, therefore, making the plant to direct most of its nutrient resources for resistance expression instead of yield. According to Nigam et al., (1991), groundnut varieties with resistance to GRD spend energy to express genes of resistance resulting in yield potential reduction. The very low yields of the local checks however, were due to severe infection of GRD and LLS. Nutter and Littrell (1996) had earlier reported that severe infection of LLS and GRD significantly reduced dry pod yield. Similarly, Wilson (2014) reported reduction in yield of GRD infected groundnut plants.

The correlation of AUDPC for LLS and GRD with LLS and GRD severity was significantly positive as expected since LLS and GRD are epidemic diseases (Amoah et al., 2016). Orondo et al. (2007) reported similar observations for AUDPC of groundnut groups Virginia, Valencia and Spanish for rosette and leaf spot resistance in Kenya. Association between yield traits and diseases were negatively correlated indicating that LLS and GRD highly contributed to the yield reduction since the plant leaf area was negatively affected as the diseases developed. The loss of leaf area at any stage of the crop growth resulted in the reduction of net photosynthetic area in which the higher the degree of defoliation or stunting the more the loss in dry pod yield. Reduction in pod dry weight by GRD infestation has been widely reported (Wilson, 2014). This meant that as the severity of the disease increased, the yield decreased significantly through the significant negative effects of GRD on both the morphological and reproductive growth of groundnut (Usman et al., 2015). Groundnut rosette disease is an active viral disease which reduces vegetative growth of the plant, causing decrease in yield potential.

The difference in performance of the tested genotypes in the two seasons was majorly influenced by rainfall. Rainfall is known to have a negative influence on movement of aphids, which are the vectors of GRD. Persistent rain dislodges aphids from plants onto the soil surface thereby exposing them to predation or they may be killed directly by soil particles splashed onto their colonies (Mugisa et al., 2016; Wightman et al., 1990). According to Hassan et al. (2009), even slight rainfall amounts quickly lowered aphid populations from fields at different times of the day. East Acholi (Kitgum District) experiences shorter rains in second season (August to December), while for West Acholi (Amuru, Omoro, Nwoya) shorter rains is the characteristic of the first season (March to June) The implication of this finding is that more stringent GRD management should be applied in seasons that are characterized by shorter rains. On the other hand, the generally high groundnut yields in Omoro could be attributed to less GRD field incidence and severity resulting from low disease pressure in the area, in addition to having favorable soils for groundnut production. Omoro has soils of the sandy clay-loam textural class to which groundnut is best adapted being well-drained, loose, friable and medium textured soils.

\section{Conclusion}

This study has shown that improved groundnuts with resistance to GRD can increase groundnut yield levels under different GRD pressure. Yield levels among the 4 groundnut genotypes varied across locations. Comparatively, lower yields were obtained in seasons characterized by shorter or lower rains. A more stringent GRD management is therefore, required in seasons and areas that are characterized by shorter and/or less rains. Overall, the 4 genotypes demonstrated host resistance under varied disease pressure, thus they could be used by farmers in the region to manage GRD in integration with other practices including early planting, correct plant spacing and control of aphid vectors.

\section{References}

Adee, E., Roozeboom, K., Balboa, G. R., Schlegel, A., \& Ciampitti, I. A. (2016). Drought-Tolerant Corn Hybrids Yield More in Drought-Stressed Environments with No Penalty in Non-stressed Environments. Fronier in Plant Science, 7, 1534. https://doi.org/10.3389/fpls.2016.01534

Amoah, R. A., Akromah, R., Asibuo, J., Oppong, A., Nyadanu, D., Agyeman, A., \& Bediako, A. K. (2016). Genetic control of resistance to rosette virus disease in groundnut (Arachis hypogaea L.). Journal of Plant Breeding and Crop Science, 8, 87-93. https:// doi.org/10.5897/JPBCS2015.0551 
Assefa, T., Abebe, G., Fininsa, C., Tesso, B., \& Al-Tawaha, A. R. M. (2005). Participatory bean breeding with women and small holder farmers in eastern Ethiopia. World Journal of Agricultural Sciences, 1, 28-35.

Bucheyeki, T. L., \& Mmbaga. T. E. (2013). On-Farm evaluation of beans varieties for adaptation and adoption in Kigoma region in Tanzania. ISRN Agronomy, 1-5. https://doi.org/10.1155/2013/436064

Busolo-Bulafu, C. M. (2004). Development of groundnut rosette disease and vector resistant varieties. Uganda Journal of Agricultural Sciences, 9, 574-577.

Fliert, E. V., Christiana, B., Hendayana, R., \& Murray-Prior, R. (2010). Pilot Roll-Out: Adaptive Research in Farmers' Worlds. Extension Farming Systems Journal, 6, 63-71.

Hassan, M. R., Ahmad, M., Rahman, M. H., \& Haque, M. A. (2009). Aphid Incidence and its Correlation with Different Environmental Factors. Journal of Bangladesh Agricultural University, 7, 15-18. https://doi.org/ 10.3329/jbau.v7i1.4791

Joshi, K. A., Musa, C., Johansen, S., Gyawali, D., Harris, D., \& Witcombe, J. (2007). Highly client-oriented breeding, using local preferences and selection, produces widely adapted rice varieties. Field Crops Research, 100, 107-116. https://doi.org/10.1016/j.fcr.2006.05.011

Kaizzi, C. K., Ssali, H., \& Vlek, P. L. (2006). Differential use and benefits of Velvet bean (Mucuna pruriens var. utilis) and $\mathrm{N}$ fertilizers in maize production in contrasting agro-ecological zones of Eastern Uganda. Agricultural Systems, 88, 44-60. https://doi.org/10.1016/j.agsy.2005.06.003

Kakeeto, R., Wambi, W., Barwogeza, M., Auma, L., Odongo, W., Ozuma, G., \& Ssekiwoko, F. (2018). Harnessing cultivar performance and stability for deploying superior groundnut plant types in the Lake Albert Crescent Zone of Uganda. African Journal of Agricultural Research, 13, 1120-1127. https://doi.org/ 10.5897/AJAR2018.13051

Khalid, E. M., Afutu, E., Odong, T. L., Okello, D. K., Nuwamanya, E., Olupot, G., ... Okori, P. (2018). Assessment of Groundnut (Arachis hypogaea L.) Genotypes for Yield and Resistance to Late Leaf Spot and Rosette Diseases. Journal of Experimental Agriculture International, 21, 1-13. https://doi.org/10.9734/ JEAI/2018/39912

Kueneman, E. A. (2002). Foreward. In P. Annicchiarico (Ed.), Genotype $\times$ environment Interactions-Challenges and opportunities for plant breeding and cultivar recommendations (FAO Plant Production and Protection Paper No. 174). Food and Agriculture Organization of the United Nations, Rome.

Madden, L. V., Hughes, G., \& vanden Bosch, F. (2007). The study of plant disease epidemics. American Phytopathological Society, St.Paul Minnesota, USA.

Maiti, R. K., \& Satya, P. (2014). Research advances in major cereal crops for adaptation to abiotic stresses. $G M$ Crops Food, 5, 259-279. https://doi.org/10.4161/21645698.2014.947861

Minde, A. S., Kamble, M. S., \& Pawar, R. M. (2017). Stability analysis for pod yield and its component traits in groundnut (Arachis hypogaea L.). Asian Journal of Biological Sciences, 12, 15-20. https://doi.org/ 10.15740/HAS/AJBS/12.1/15-20

Mugisa, I. O., Karungi, J., Akello, B., Ochwo-Ssemakula, M. K. N., Biruma, M., Okello, D. K., \& Otim, G. (2016). Determinants of groundnut rosette virus disease occurrence in Uganda. Crop Protection, 79, 117-123. https://doi.org/10.1016/j.cropro.2015.10.019

Nigam, S. N., Dwivedi, S. L., Rao, Y. L. C., \& Gibbons, R. W. (1991). Registration of ICGS-1 peanut cultivar. Crop Science, 31, 1382-1383. https://doi.org/10.2135/cropsci1991.0011183X003100050071x

Nutter, F., \& Littrell. R. (1996). Relationship between defoliation, canopy reflectance and pod yield in the peanut late leaf spot patho-system. Crop Protection, 15, 135-142. https://doi.org/10.1016/0261-2194(95)00084-4

Obuo, J. E. P., Nangoti, N., Nalyongo, P., Akurut-Akol, H., \& Otutu, J. (2004). Community based groundnut seed production, and dissemination for sustainable smallholder agriculture in Teso farming system (SAARI Final Technical Report TPF 36).

Okello, D. K., Akello, B. L., Tukamuhabwa, P., Odong, T. L., Adriko, J., Ochwo Ssemakula, M., \& Deom, C. M. (2014a). Groundnut Rosette Disease Symptoms types distribution and management of the disease in Uganda. African Journal of Plant Science, 8, 153-163. https://doi.org/10.5897/AJPS2014.1164

Okello, D. K., Biruma, M., \& Deom, C. M. (2010). Overview of groundnuts research in Uganda: Past, present and future. African Journal of Biotechnology, 9, 6448-6459. https://doi.org/10.5897/AJB09.013 
Okello, D. K., Monyo, E, Deom, C. M., Ininda, J., \& Oloka, H. K. (2013). Groundnuts production guide for Uganda: Recommended practices for farmers. National Agricultural Research Organisation, Entebbe.

Okello, D. K., Okori, P., Puppala, N., Ureta, B. B., Deom, C.M., Ininda, J., ... Asekenye, C. (2014b). Groundnuts seed production manual for Uganda. National Agricultural Research Organisation, Entebbe.

Okello, D. K., Ugen, M. A., Otuba, M, O., Okori, P., Monyo, E. S., Akpo, E., \& Deom, C. M. (2017). Current status of groundnut improvement in Uganda. TLIII, Uganda. Retrieved from https://tropicallegumeshub. com/rc/current-status-of-groundnut-improvement-in-uganda

Payne, R. W., Murray, D. A., Harding, S.A., Baird, D. B., \& Soutar, D. M. (2011). GenStat for windows (17th ed.). VSN International, Hemel Hempstead, UK.

Powell, N., Xuemei, J. R., Edlington, J., \& Dolferus, R. (2012). Yield stability for cereals in a changing climate. Functional Plant Biology, 39, 539-552. https://doi.org/10.1071/FP12078

Rachier, G. O. (2005). Groundnut production, Research status and future prospects in Western Kenya. Proceedings of Groundnut Stakeholders Meeting, Tuesday, June 14, 2005, KARI Headquarters Conference Hall (pp. 13-21).

Sahoo, P. R., Ananth, P. N., Nandi, S., Sundaray, J. K., \& Jayasankar, P. (2017). Early breeding and seed production of Indian Major Carps. Attributes of Innovations from an adaptive trial. Current Agriculture Research Journal, 5, 58-65. https://doi.org/10.12944/CARJ.5.1.07

Scoones, I. (2009). Livelihoods perspectives and rural development. Journal of Peasant Study, 3, 171-196. https://doi.org/10.1080/03066150902820503

Shiferaw, B., Muricho, G., Okello, J., Kebede, T. A., \& Okecho, G. (2010). Adoption of Improved Groundnut Varieties in Uganda (Research Report No. 5, p. 36). Andhra Pradesh, India: International Crops Research Institute for the Semi-Arid Tropics.

Sibiya, J., Tongoona, P., Derera, J., \& Makanda, I. (2013). Smallholder farmers' perceptions of maize diseases, pests, and other production constraints, their implications for maize breeding and evaluation of local maize cultivars in KwaZulu-Natal, South Africa. African Journal of Agricultural Research, 17, 1790-1798. https://doi.org/10.5897/AJAR12.1906

Storey, H. H., \& Ryland, A. K. (2008). Transmission of groundnut rosette virus. Annals of Applied Biology, 43, 423-432. https://doi.org/10.1111/j.1744-7348.1955.tb02492.x

Trouchea, G., Weltzienb, E., Barro-Kondomboc, C. P., Gozé, E., \& Chantereaua, J. (2010). Participatory variety development for sorghum in Burkina Faso: Farmers' selection and farmers' criteria. Field Crop Research, 119, 183-194. https://doi.org/10.1016/j.fcr.2010.07.005

Usman, A., Ofori, K., Danquah, E. Y., Offei, S. K., \& Ado, S. G. (2015). Genetic analysis of groundnut rosette virus disease in groundnut (Archis hypogaea L.). African Journal of Plant Science, 9, 115-123. https://doi.org/10.5897/AJPS2015.1264

Wightman, J. A., Dick, K. M., Ranga Rao, G. V., Shanower, T. G., \& Gold, C. G. (1990). Pests of groundnut in the semi-arid tropics. Insect Pests of Tropical Food Legumes (pp. 243-322). John Wiley \& Son, England.

Wilson, C. R. (2014). Applied plant virology. CABI Press, Wallingford, UK. https://doi.org/10.1079/ 9781780644257.0000

\section{Copyrights}

Copyright for this article is retained by the author(s), with first publication rights granted to the journal.

This is an open-access article distributed under the terms and conditions of the Creative Commons Attribution license (http://creativecommons.org/licenses/by/4.0/). 